\title{
THE CONCEPTUAL OF SUSTAINABLE SETTLEMENT WITH PARTICIPATORY APPROACH
}

\author{
Fuad Zubaidi
}

Department of Architecture, Tadulako University

e-mail: fhoead@yahoo.co.id

\begin{abstract}
Sustainable development of settlement is an attempt to improve the quality of human life from the aspect of environmental sustainability, social, or economic, which is done to integrate and harmonize three aspects. Donggala Kodi is one of the areas included in the administrative boundaries of the Palu city which a with fairly steep slope topography and height of 200m. Under these conditions, in principle, to make into one of the proneness. Development of settlement areas by utilizing its asset base, need to specify the form of the space requirements, related social, economic and environmental. This is to achieve sustainable development, as well as how to address the imbalance that exists. Participatory approach with the involvement of the community in order to draw up conceptual sustainable settlements is one effective approach to solve the problem. This paper discusses how the preparation of conceptual framework of sustainable settlements with community participation approach. The result of the discussion related to the formulation of the concept of residential development on the socio-economic empowerment of the community, and using the environment-based community.
\end{abstract}

Keywords: settlement, sustainable, participatory approach

\begin{abstract}
ABSTRAK
Perkembangan permukiman yang berkelanjukan memiliki tujuan untuk mengembangkan kualitas hidup manusia dari aspek keberlanjutan lingkungan, sosial dan ekonomi yang dilakukan dengan bersinergi dan harmonis. Donggala Kodi merupakan salah satu kawasan yang termasuk ke dalam batas wilayah Kota Palu yang memiliki topografi berbukit lembah dan ketinggian $200 \mathrm{~m}$ dari permukaan laut. Dengan kondisi seperti ini prinsip untuk menyatukannya adalah dengan mengembangkan area permukiman menggunakan dasar asset, kebutuhan untuk spesifikasi persyaratan ruang yang melibatkan sosial, ekonomi dan lingkungan. Hal ini untuk mencapai pengembangan berkelanjutan juga untuk mengetahui ketidak seimbangan yang terjadi. Pendekatan partisipatori dengan melibatkan komunitas untuk menggambarkan konsep permukiman berkelanjutan merupakan salah satu pendekatan
\end{abstract}


untuk menyelesaikan masalah. Penelitian ini mendiskusikan bagaimana persiapan kerangka konseptual dari permukiman berkelanjutan dengan pendekatan partisipatori pada komunitas. Hasil penelitian berhubungan dengan perumusan konsep pengembangan perumahan dalam hal penguatan sosial-ekonomis komunitas dan penggunaan komunitas berbasis lingkungan.

Kata kunci: permukiman, berkelanjutan, pendekatan partisipatori

\section{INTRODUCTION}

In recent years in the country of Indonesia has suffered natural disasters on a small scale and large scale of the damage and destroyed many functions especially in infrastructure and housing. Donggala Kodi as one of the region Central Sulawesi town of Palu has a with a fairly steep slope topography. The disaster happened on a long term of economy impact, such as slow growth, falling incomes and income distribution opportunities damage.

The condition had caused people especially those on disaster prone areas on their worst condition and has created a very tough challenge for government society to carry out the recovery process for the damage settlement, and should immediately undertake the recovery process or development of sustainable residential which aware to disaster.

Resolution approaches have often aimed at short-term support has nothing to do with the ongoing settlement construction, the role and ability of local as well as the social, economic and cultural diversity, income distribution opportunities.

Development paradigm has shifted to efforts to increase community participation in various phases of development activities primarily on the develop-ment of sustainable settlements. Implementation of the principle of putting people in addition to being the object of development is also a subject or agents of develop-ment that is expected to develop a program of sustainable development as well as to solve their own problems, especially in improving the environmental quality of settlements.

Donggala Kodi as one of the disaster-prone areas in Central Sulawesi has been implementing various settlement processes with the processes that focus on participatory approaches can direct the course of early development, sustainable growth and control the physical environment changes, and realize effective space utilization, effective and in accordance with local specific development environments.

\section{THEORY / RESEARCH METHODS}

\section{Sustainable Development}

Sustainable development is defined as development or development that meets the needs of the present without harming the ability of future generations to meet their needs. The challenge of sustainable development is to find ways to improve the wel- 
fare of using natural resources, wisely which must be based on three general aspects of sustainable development, namely social, economic, and environmental. The concept of sustainable development is not only intended for the harmony of the environment but also for long-term sustainability of the natural resource-based.

Sustainable housing development can not be separated from some related issues with the difference of development opportunities among actors with an inequality of infrastructure service, urban service, housing and space for business opportunities. Holmberg ed. (1992) in Harris, (2000) In the extensive discussion and use of the concept since then, there has generally been are cognition of three aspects of sustainable development :

1. Economic: An economically sustainable system must be able to produce goods and services o $\mathrm{n}$ a continuing basis, to maintain manageable levels of government and external debt, and to avoid extreme sectoral imbalances which damage agricultural or industrial production.

2. Environmental: An environmentally sustainable system must maintain a stable resource base, avoiding over-exploitation of renewable resource systems or environmental sink functions, and depleting non-renewable resources only to the extent that investment is made in adequate substitutes. This includes maintenance of biodiversity, atmospheric stability, and other ecosystem functions not ordinarily classed as economic resources.

3. Social: A socially sustainable system must achieve distributional equity, adequate provision of social services including health and education, gender equity, and political accountability and participation.

\section{Empowerment and Participation}

The concept of empowerment includes the meaning of community development and focused on community-based development (Chamber, 1995 in Kartasasmita, 1997). Community participation is a technical process to provide opportunities and wider authority for community to join in solving problems. The division of authority is based on the level of community participation (level of involvement) in these activities.

Public participation aims to find better solutions problems in the community by opening up more opportunities for people to participate in giving contribution so the implementation is more effective, efficient, and sustainable.

Arnstein (1969) describes participation as a meaning where citizens can influence important social change, which can make them share the benefits of society. Participation is defined as involvement of mental / thoughts and emotions / feelings in group situations that encourage them to contribute to the group in order to achieve goals and take responsibility for the business in question.

In it there are three elements (ideas) which are:

1. Participation is really a mental engagement and feeling, more than just a physical involvement.

2. Willingness to give something contribution to the attainment of group goals. It means that there is a sense of fun, volunteerism to help the group.

A person becomes a member of the group with all its value. 
3. Responsibility is a prominent aspect of the sense of being a member. Recognized as a member means that there is a sense of "sense of belonging".

\section{Participation and Community Needs}

Muhaimin (1987) argues that the theory of public participation can be viewed in two dimensions, namely: the social dimension and the dimension of modernity. These dimensions looks at the nuances participation horizontally and vertically. For the social dimension proposed by Muhaimin (1987) as follows:

1. The general pattern: community participation in development activities of government and non-government almost balanced. That is, if there is cooperation between them, which is manifested in semi-government activities, therefore participation in these activities is likely to increase

2. Dualistic pattern: community participation in the activity of non-governmental higher than participation in government-sponsored development activities. In other words, the activity of non-governmental driven more able to attract the support of the community rather than a government-sponsored. If this is true, then it could be due to the activities of the government which are not managed properly.

\section{Research Methods}

The study was conducted with a naturalistic approach, a major force in solving problems with community involvement and active researchers in the field. The formulation of the concept also consider theories of sustainable settlements and participatory planning structuring settlements.

\section{RESULTS AND DISCUSSION}

Sustainable settlements in disaster prone areas, need to be harmonized with the policies and programs that exist in government. Synchronize the planning and execution of a series of programs to streamline the implementation of settlement activities in order to provide optimal results, the power-to-use and manage. Development policy by the government using PNPM-Mandiri through the ND / PLPBK is Settlement and Environment Arrangement with Community-Based Program or Neighborhood Development (ND) is the culmination of the National Program for Community Empowerment (PNPM-Mandiri) is also an integral part of the Program Counter Urban Poverty (P2KP). Where people get this program is considered to have achieve the self towards civil society. PLPBK is one approach that is quite effective and sustainable settlements.

To achieve these objectives, the main settlement in quality improvement aimed at the realization of sustainable development, integrated, balanced, and harmonious inter-sector in utilizing the space for settlement activity. 


\section{Participatory Planning Sustainable Settlements in the Donggala Kodi}

Donggala Kodi as one of the disaster-prone location of residential areas, in the preparation of the conceptual development of sustainable settlements actively involve the community in the process of identification, analysis until the development plans of sustainable settlements.

Some stages of the preparation of conceptual settlement planning undertaken by several stages:

1. Building community capacity as social capital development.

2. Mapping existing condition Donggala Kodi region by researchers and the public to self mapping method, transect mapping and behavior, as well as combined with the spatial planning of the city.

3. Identify potential and the settlements to the base rate.

4. Discuss excavation vision and mission settlements grassroots development.

5. Excavation of idea generation in the Donggala scores of sustainable settlements.

6. Focus group discussions (FGD) and formulation of potential problems and the preparation of development plans and thematic structuring settlements.

7. Preparation of conceptual structuring of community-based sustainable neighborhoods.

Figure 1, 2, 3, 4, 5, 6,7 and 8 show:

1. Administrative boundaries of the region Donggala Kodi as one disaster-prone areas of Palu city.

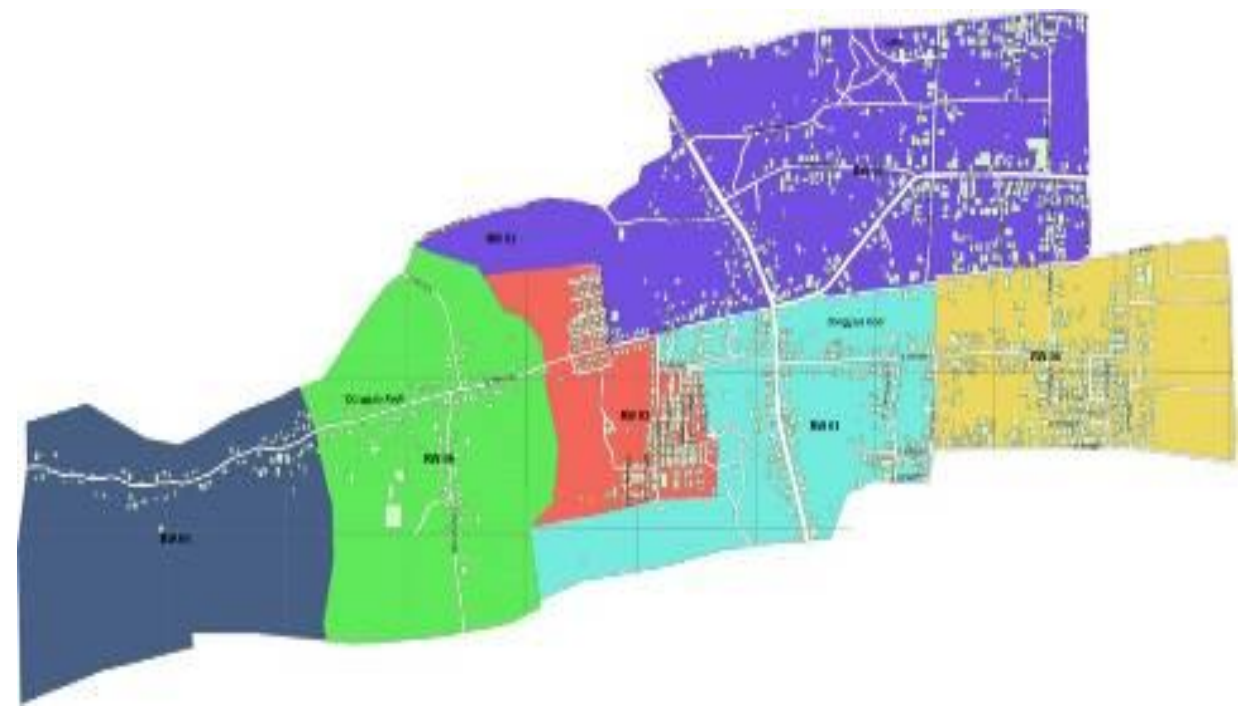

Figure 1. Donggala Kodi Administrative Region Map Source: mapping governmental 
2. Process mapping carried by society to identify existing conditions areas. Self Mapping categorization was accompanied researchers to perform data retrieval.

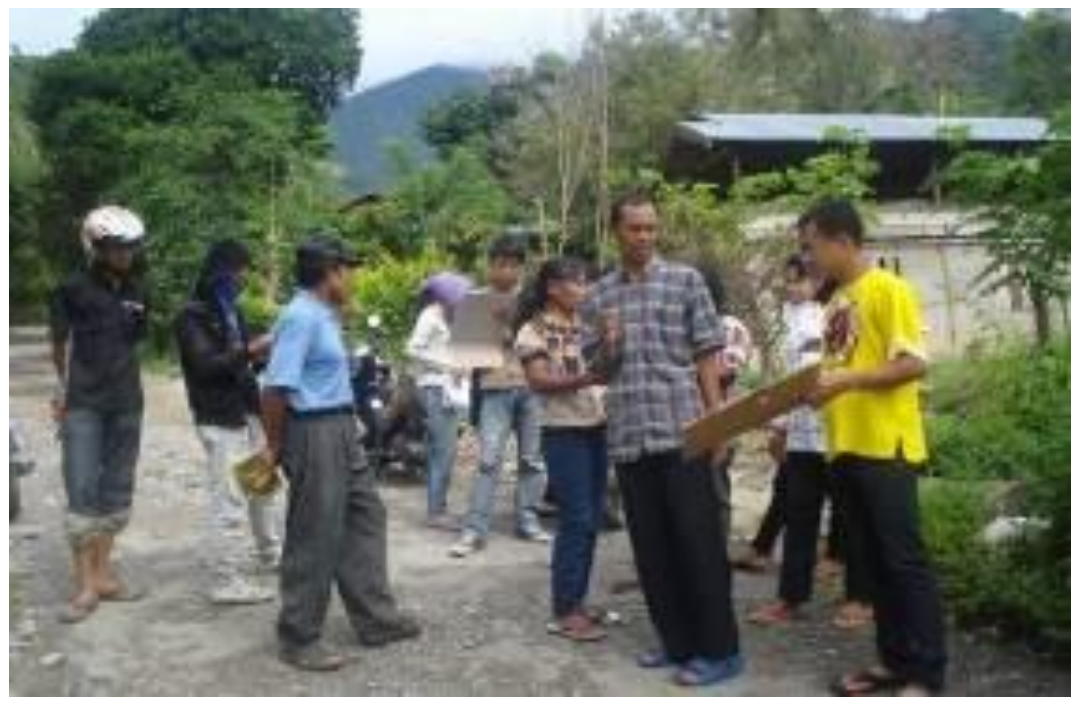

Figure 2. Public Self Mapping Source: field survey

3. The process of identifying potential problems in the region and to further explore information about the environment and how the related settlement of existing problems and potential. Potential and problems of data used to develop the terms of reference the sustainable settlement.

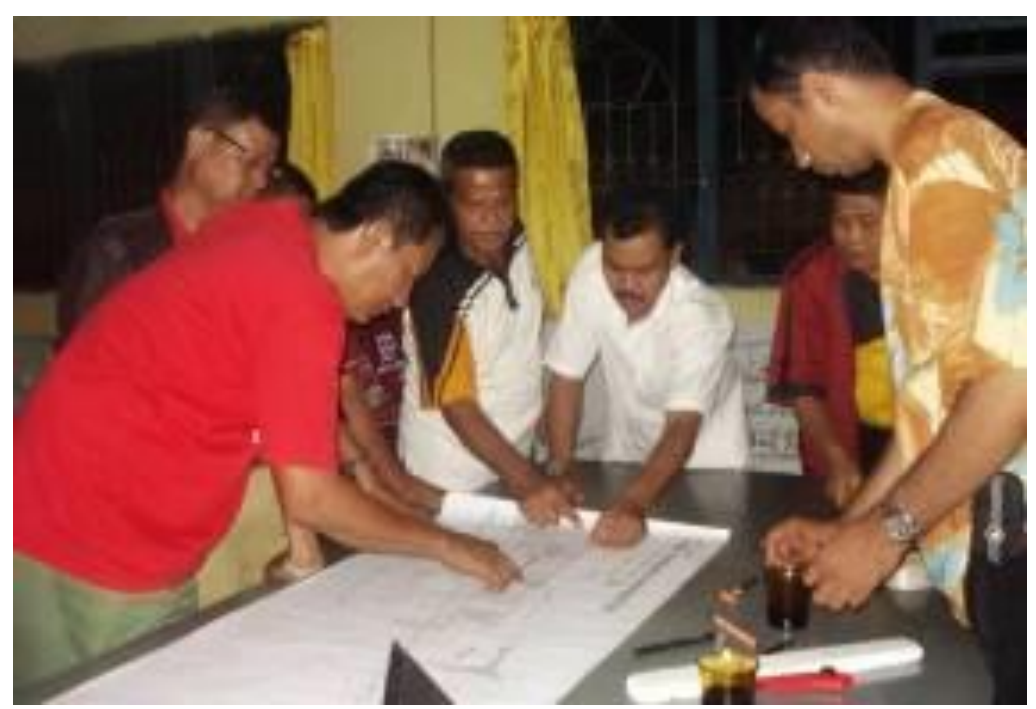

Figure 3.Identify Problem and Potential of Settlements

Source: personal documentation 
4. The process of drawing "Kampung Impian" (Dream Village) by children to explore how the vision of the future settlement desired by the children as the next generation.

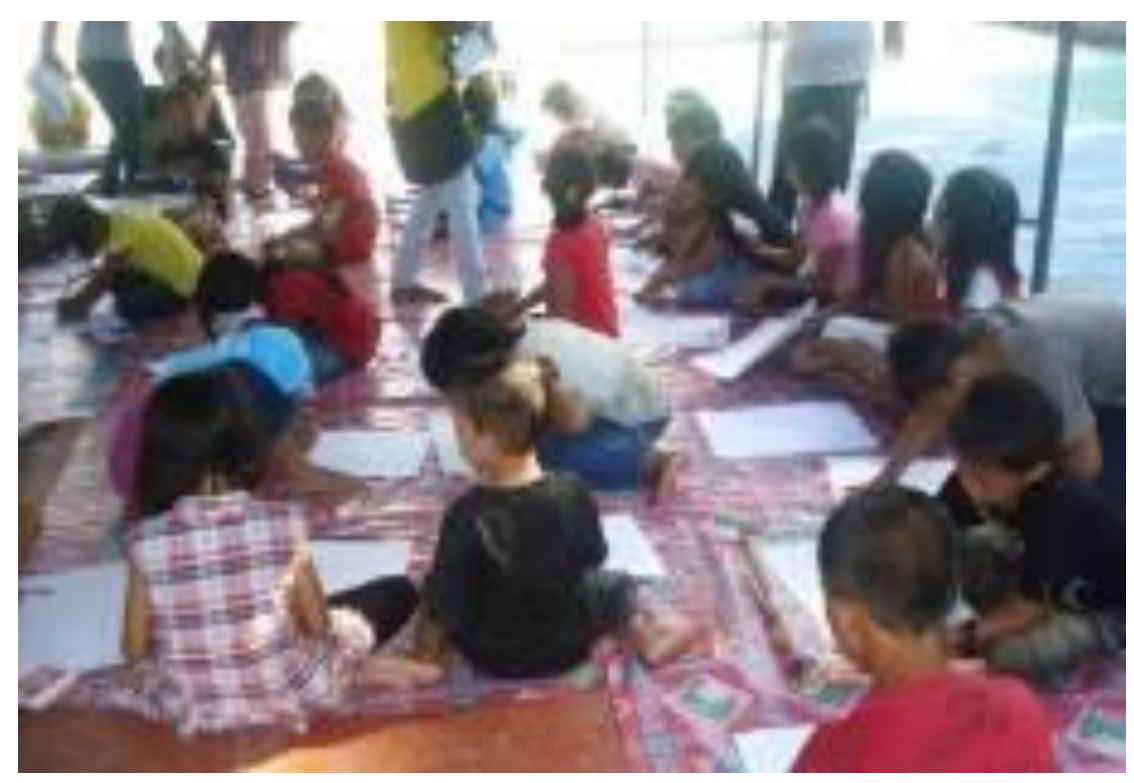

Figure 4. Drawing "Kampung Impian" Contest Source: personal documentation

5. Some of the resulting images that saw how children want their settlement in the future.

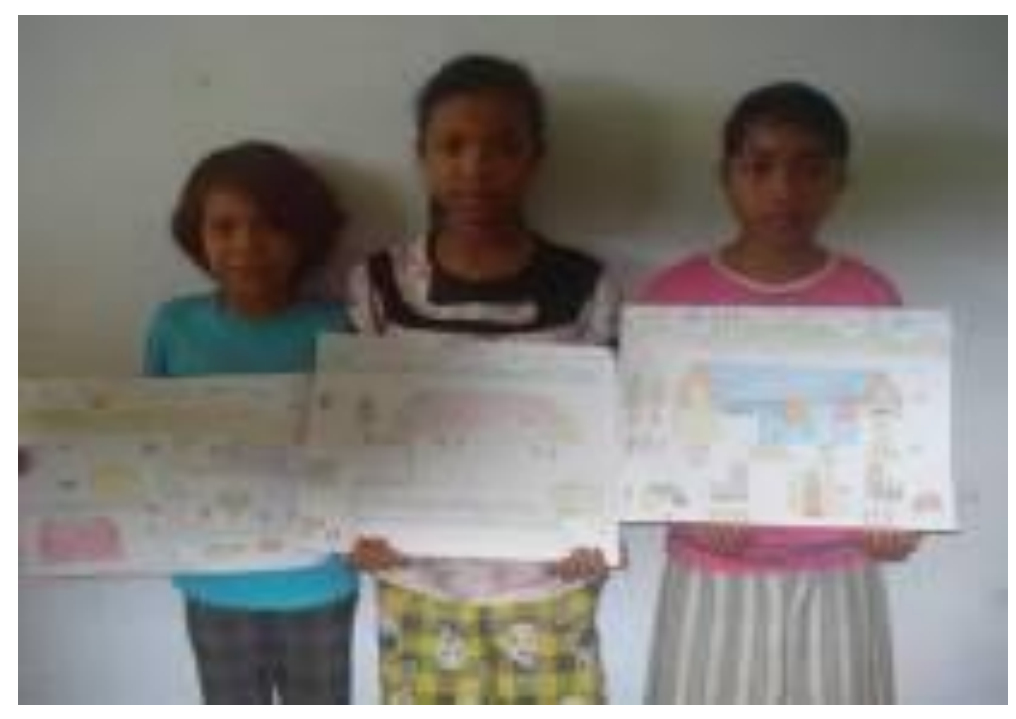

Figure 5. Drawing "Kampung Impian" Contest Source: personal documentation 
6. Focus group discussions were conducted at the base by the community to harmonize how willing people with potential and existing problems.

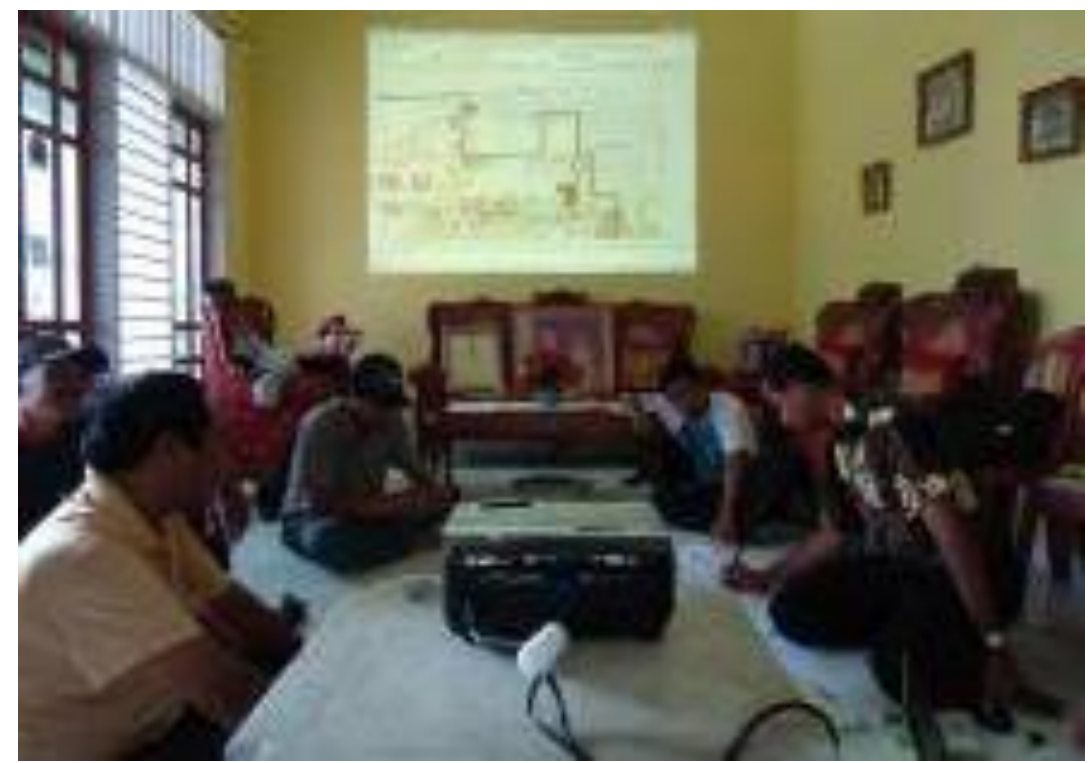

Figure 6. Focus Group Discussion

Source: personal documentation

7. Focus group discussions were conducted at the base by the community to sync with regional development plans.

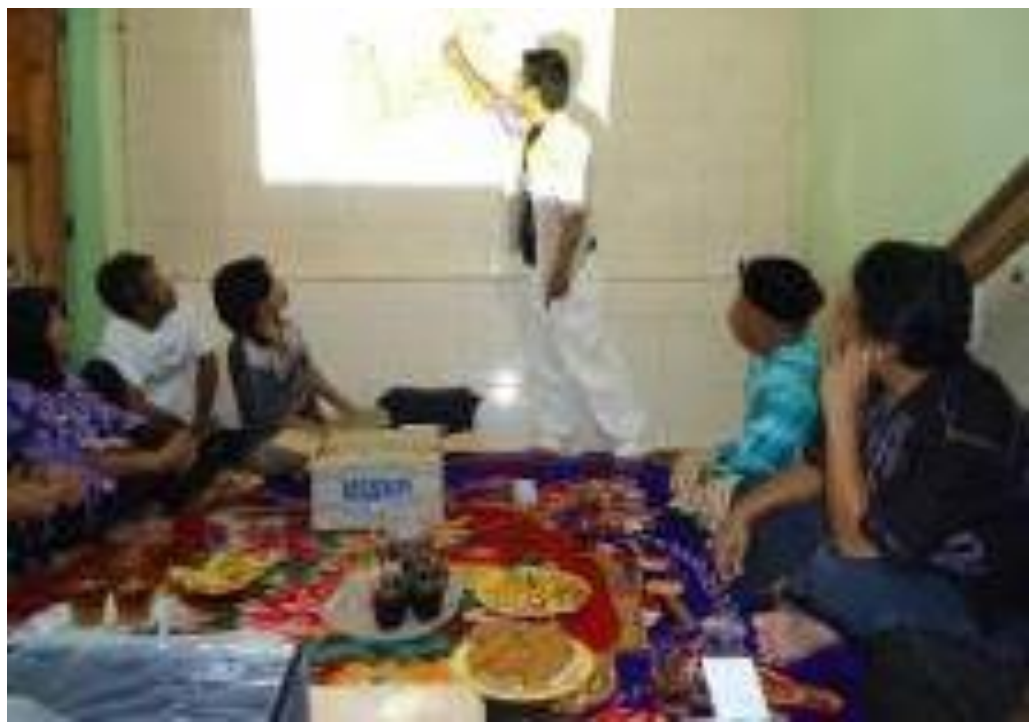

Figure 7. Focus Group Discussion

Source: personal documentation 
8. Preparation of drafting a conceptual framework neighborhoods with community involvement through the development of ideas. Conceptual framework developed further socialized to the general public to get community feedback.

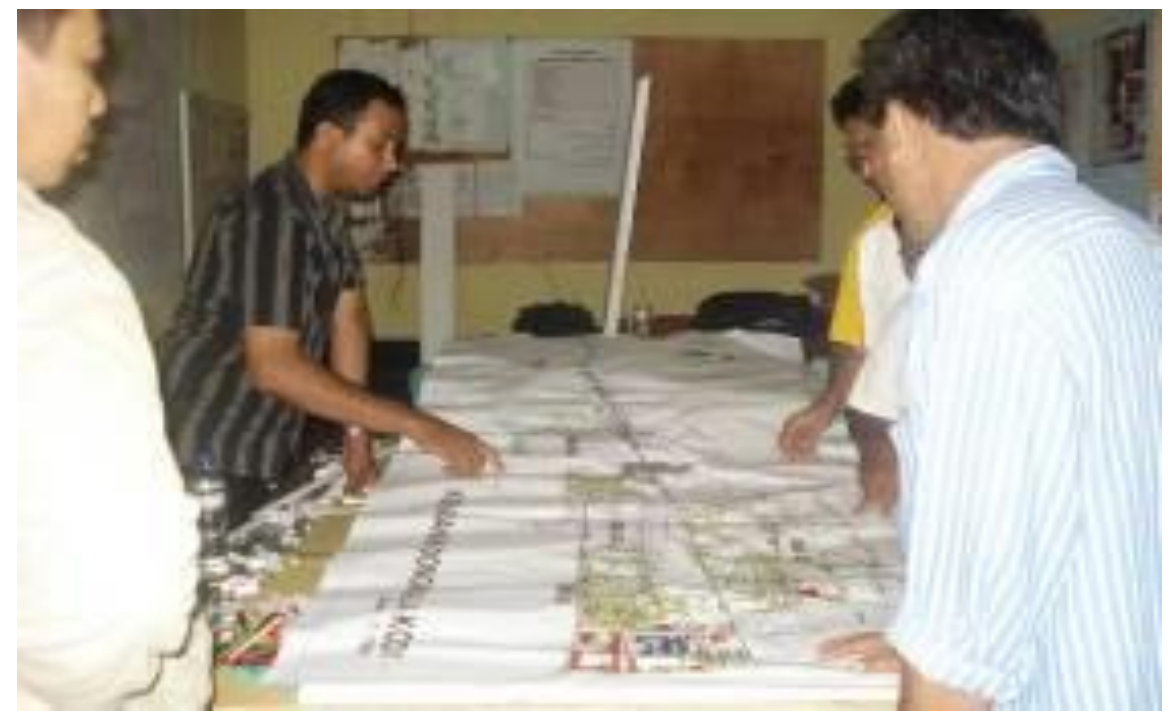

Figure 8. Preparation of Conceptual Structuring

Source: personal documentation

\section{Development of Social Capital Based Settlements}

PLPBK/ND program in the community is one of the community-based approach has the power to build social capital in the development of sustainable settlements. Community management of social capital formed by the power of innovation and creativity gave birth to the community to utilize its resources towards the economic, social, and environmental settlements harmonious, and sustainable, productive, and self identities and the synergy between public and government.

Development of communities as social capital in the development of sustainable settlements especially in disaster-prone areas should be begun by strengthening people's behavior based universal values (togetherness, family, volunteerism, honesty) that underlies the values of local wisdom as social capital that strengthens community order with other members of the community to strength each other, so as to create an ethical culture, respect the laws and regulations, respect the rights of others, orderly, clean, healthy and productive.

\section{Potential and Sustainable Settlements under Joint Rule}

Sustainable settlement planning implemented in the Donggala Kodi as a disasterprone areas, carried out by identifying the potential and problems of the environment and the resources that are formulated based on the discussed results of citizens in general and at the grassroots communities through Focus Group Discussion 
(FGD). Identify potential and existing problems mapped according to the condition and placement of the location where the presence or potential problems in the sphere region Donggala Kodi. In the process of preparing a conceptual settlement, the principles of the indigenous people contributed to the effort of planning and structuring settlements, because it is in principle binding the community how to take action related to the use and development of settlements. These principles are agreed upon as "common rules" in society.

The principles / rules with, among others, regulate:

1. Solidarity: this residential neighborhood development efforts should be a shared responsibility with emphasis on the most vulnerable through mutual aid efforts.

2. The agreement rules: all decisions regarding the planning or execution of the settlement should be based on need and a mutually agreed rules.

3. Creative: society must optimize the potential and conditions of settlement as the local potential that can be utilized optimally to carry out the development of sustainable neighborhoods.

4. Innovative: society in defining the types of activities or programs that are not just manage existing resources, but it is more, seeking to create the resources needed.

5. Prioritize local capacities: as a key to sustainable development (sustainable development) oriented to building the capacity of communities themselves.

6. Accountability: society must be able to account for the tasks and actions to the public and is always ready to be sued.

7. Stresses partnership and collaboration: development of community-based sustainable settlements associated with various stakeholders, such as local government.

\section{Basic Conceptual Development of Community-Based Settlement}

In line with the principles and approach to the development of community-based housing that is responsive to the possibility of disaster, the public and the parties relating to the construction of settlements must observe and comply with several provisions of the following basis:

1. Catalyzing the process of how the position of the government in his participation as a development leader.

2. Sustainable development and structuring settlements must meet the eligibility requirements of technical and non-technical.

3. Communities should be involved as a key player in the decision making process during planning, implementation, monitoring and evaluation.

4. In the process of selection of materials, construction technology and infrastructure for housing should apply sustainability criteria of social, economic and environmental as well as to consider the possibility of a natural disaster.

5. Neighborhoods realignment activities should be seen as an effort to lay the foundation for long-term development of better social, economic and environmental. 


\section{CONCLUSIONS}

The process of planning / structuring sustainable neighborhoods that require optimal effort aims and objectives can be achieved. Often the planning and building of settlements are not on target because they do not actively involve the community from the beginning of the planning process and identify the main needs in areas prone to enter the category needs to be addressed specifically. In preparing the conceptual framework of sustainable settlements optimizing community involvement is very important because the more people know exactly on the conditions.

The results achieved in a sustainable settlement planning program of community-based optimal and more effective and can solve the problem. Because the intensity of social interaction that is done by society has a strong influence on the level of community participation in the development and structuring settlements. Some things can be summed related drafting a conceptual framework of sustainable settlement planning:

1. Infrastructure and housing needs with respect to improving the quality of housing has a significant effect on participation.

2. Ongoing settlement construction management model of participatory community based, able to solve a variety of environmental issues and settlements that exist in society. Community involvement from the planning stage up to the formulation of the next program, the local community with community leaders act to develop synergies between the development process as leaders, and the public.

\section{REFERENCES}

Arnstein, S. (1969), A Ladder of Citizen Participation, The Jurnal of the American Institute of Planners, Vol.35 no. 4. USA.

Cahyani, D. (2008), Revitalization of the Taman Sari Valley with Empowerment Through Community Organization, Teras Journal, 8 (1), Juli 2008.

Devis, K.and Newstorm, J.W. (1989), Behavior in Organizations, Erlangga, Jakarta.

Harris, J. M. (2000). Basic Principles of Sustainable Development, Global Development and Environment Institute, Tufts University.

Kartasasmita (1997), Poverty, Balai Pustaka. Jakarta.

Kusuma, S. W. (2002), Build Institusi Warga for Poverty Handling Cases of experience in urban Poverty Project, Social Analysis Journal, 7 (2), June 2002.

Muhaimin, Y. (1987), Starting Development Issues in Indonesia, Institute for Community Indonesia, Grafitakama Offset, Jakarta.

Ramos, E. and Ramón, A. A. (1980), Community Participation Model, In Community Participation in Delivery Urban Services in Asia, World Bank.

Siahaan, N. (2012), Conceptual Model Recovery of Sustainable development, Journal of Architecture and Urban KORIDOR, 3, Medan.

Oetomo, A. (1997), Conception and Implementation Implications of Community Participation in Spatial Planning in Indonesia, Journal of Urban and Regional Planning, Vol 8 Number 2 April 1997, ITB, Bandung. 
This page intentionally left blank 